\title{
Yenilenen Kentlerde Nostaljik Söylemler ve Kurgusal Mekânlar
}

\section{Nostalgic Discourses And Fictionals Spaces In The Renewed Urban}

Rukiye Satılmışa,*

${ }^{a}$ Dr. Öğr. Üyesi, Muş Alparslan Üniversitesi, Fen Edebiyat Fakültesi, Sosyoloji Bölümü, Muş/Türkiye. ORCID: 0000-0002-0304-0361

\section{MAKALE BİLGİS \\ Makale Geçmiși:

Anahtar Kelimeler:
Kent
Kentsel yenileme
Nostalji
Yeniden üretim

Başvuru tarihi: 28 Eylül 2018

Düzeltme tarihi: 03 Mart 2019

Kabul tarihi: 27 Mart 2019

\section{A RTICLE INFO}

\section{Article history:}

Received 28 September 2018

Received in revised form 03 March 2019

Accepted 27 March 2019

Keywords:
The City
Urban renewal
Nostalgia
Re-Production

ÖZ

Yaklaşı on-onbeş yıldır yenileme geçiren kentlere bakıldığında, gerek yeni yapıların inşaa edilip pazarlanma sürecinde gerek eski yapıların restore edilme sürecinde 'nostaljik' söylemlerin payının yadsınamayacak derece olduğu görülmektedir. Yatırımcılar yeni inşa ettikleri konutlarının nostaljik reklamlarında geçmişin güzel, sakin ve huzur dolu eski günlerini müşterilerine vaat ederken, yerel yönetimler ise tarihi yapıları restore ederek geçmişin nostaljik günlerini canlandırdıklarını iddia etmektedirler. Bu durum sadece mekânların yapım ya da onarım süreçlerine değil aynı zamanda nosatlji kafe örneğinde olduğu gibi kullanım biçimlerine de yansımaktadır. Diğer bir deyişle sürekli bir dönüşüm sürecinde olan kentlerde bir taraftan yeni yapılar inşaa edilip eski yapılar onarılıyorken diğer taraftan da yeni yaşam şeklinin yanında özellikle sınırlı bir alanda eskiyi yad etme ve yaşatma çabası dikkat çekmektedir. Bu makale, kentlerdeki iki önemli aktörün, yatırımcılar ve yerel yöneticilerin, nostaljik söylemlerinin kent yenileme çalışmaları açısından ne gibi anlamlar ifade ettiğini sorgulamayı amaçlamaktadır. Bu bağlamda çalışmada nostaljinin kent hayatındaki etkisi üzerinde durularak kent ve nostalji ilişkisi değerlendirilmektedir.

\section{Giriş}

Bugün birçok kent çok kısa sürelerde ve oldukça yoğun bir biçimde yeni binaların yapımına sahne olmaktadır. Bu yeni binalar ile kısa sürede büyük değişimler geçiren kentlerde iki yönlü bir yapılaşma şeklinin olduğundan bahsetmek mümkündür. Herzfeld'in ifadesiyle, arzulanan bir modernliğe doğru koşusunda kent, eskiden kullanılmayan binaların bugün çılgınca yeniden inşa edilip şekillendirilmesinin de yolunu açmıştır (2011: 407). Başka bir ifadeyle, bir yandan yeni binalar yapıllyorken diğer yandan ise eski binalar restore edilmektedir. Kentin yeni

\footnotetext{
* Sorumlu yazar/Corresponding author

e-posta: r.kaya@alparslan.edu.tr
} 
formuna geçişte ara işlev gören bu eski binalar, atfedilen kutsallık ve gösterilen saygı ile diyebiliriz ki eskiyi ve geçmişi idealize etmekte kentlilerin nostaljik duygularını canlı tutmaktadir.

Kentlerde nostaljinin görüldüğü alanların başında özellikle eski kent merkezlerinde bulunan bu yapilar gelmektedir. Yenilenen kentlerde nostaljiyi restore yapılar dişında başka bir çok yerde daha gözlemlemek mümkündür. Eski ulaşım araçlarının nostaljik fotoğraflarının sergilendiği yeni bir metro istasyonunda, tarihi ve kültürel öneme sahip nesnelerin yerleştirildiği kent meydanlarında, bir odası şark köşesi olarak düzenlenen evlerimizde... Dikkate değer bir nokta var ki nostalji en çok, yeniliğin olduğu bir yerde ortaya çıktığında dikkat çekmektedir. Günümüzde nostaljinin anlamını ele veren ise en çok yeni mekânlarlarda karşılaşılan nostaljik figür ve düzenlemeler olmaktadır. Bu bağlamda kentler söz konusu olduğunda da yakın zamanda inşåa edilmesine rağmen nostaljik bir izlenim veren özellile bu amaçla tasarlanan mekânlar üzerinde düşünülmeyi hak etmektedir. Dolayısıyla nostaljiyi sadece geçmişin güzel günlerini yad etmek olarak değerlendirmemek, söz konusu söylem ve eylemlerin işlevlerine odaklanmak hatta bu söylemlerin kentlerde makes bulmasının nedenlerini kentlerdeki gündelik hayat açısından sorgulamak gerekmektedir. Çalışma temelde kent ve nostalji arasındaki bu ilişkiyi sorgulamayı ve aynı zamanda bununla literatürdeki nostalji üzerine yapılmış çalışmalara katkı sağlamayı amaçlamaktadır.

$\mathrm{Bu}$ amaç doğrultusunda çalışmada öncelikle tarihsel süreç içerisinde nostalji kavramının yaşadığı dönüşüm ele alınmakta ve nostaljinin bugün hangi alanlarda ve ne gibi işlevlerle ortaya çıktığına bakılmaktadır. Bu bağlamda günümüzdeki nostaljiyi anlamada kilit öneme sahip yeniden üretim kavramına başvurulmuş ve yeniden üretim üzerine yapılan tartışmalar bağlamında nostaljinin farklı alanlardaki yeniden üretimi üzerine değerlendirmeler yapılmıştır. Sonrasında ise çalışmanın odak noktası olan kentlerdeki nostalji ve yeniden üretiminin yatırımcılar yerel yönetimler açısından neler ifade ettiğine kentlerin özellikleri bağlamında bakılmıştır.

\section{Nostalji Kavramı}

Öncelikle belirtmek gerekir ki nostalji tartışmalı bir konudur; çünkü Sarlo'nun da ifade ettiği üzere; “geçmiş, her zaman tartışmalıdır" (2001: 9). Bunun temel sebebi ise geçmişin çoğunlukla kasıtlı ya da kasıtsız olarak olduğundan farklı hatırlanmasıdır. Nostaljik bakışla geçmiş, dünya savaşları, ölümcül hastalıklar, devasa felaketler ve büyük ölçekli afetlerle dolu olmasına rağmen, paradoksal olarak nostaljik olarak hatırlanma eğilimi gösterir ve genellikle kusursuz ya da eksik dönem olarak idealleştirilir (Demir, 2017: 55).

Yunanca'dan gelen nostos (eve dönüş) ve algia (özlem) kelimelerinin birleşiminden oluşan nostalgia/nostalji sözcüğünü ilk olarak İsviçreli Johannes Hofer, 1688'de yazdığı tıp tezinde, kişinin kendi memleketine geri dönme arzusundan kaynaklanan üzgün ruh halini tanımlamak için kullanmıştır (Hofer'dan akt. Boym, 2009: 25). Nostalji kavramı başlangıçta Hofer tarafindan bir hastalığı tanımlanmak için kullanılmış olsa da sonraki dönemlerde kavrama farklı anlamlar yüklenmiş ve bugün geçmiş zamana ait yer, olay ya da kişilere duyulan aşırı özlemi ifade eden olumlu bir anlam kazanmıştır. Boym'un da ifade ettiği üzere, anlamındaki olumlu değişime bağlı olarak, "19. yüzyılın ortalarına gelindiğinde nostalji, ulusal ve bölgesel müzelerde ve kent abidelerinde kurumsallaşıp kamusal bir üslup ve mekân kazanmıştır” (2009: 25). 20. yüzyılın ikinci yarısından sonra ise yapılan araştırmalar sonucunda pozitif bir duygu durumu olarak tanımlanmıştır. Söz konusu süreçte nostaljinin tedavi edilebilir bir hastalıktan moral bir değere dönüştüğünü söylemek mümkündür. Bunun da ötesinde bugün, nostaljinin ve nostaljik söylemlerin hafizanın kurgusallığından beslenen yapısından hareketle, zengin bir anlam içeriğine sahip olduğu; ekonomide, siyasette, mimaride hatta gündelik hayatın pek çok alanında kullanıldığ1 gözlenmektedir. "Nostalji literatürde tıp tarihinin bir parçası olmasına karşın, bu kavramın sosyolojiye egemen olan nostaljik paradigma nosyonuna işe yarar şekilde dönüştürebileceğini” belirten Stauth ve Turner'e göre, "sosyolojik analizin en güçlü metaforlarından biri, nostaljidir" (1997: 59-61). Geçmiş, şimdi ve gelecek arasında zamansal açıdan olduğu gibi mekânsal açıdan da geçişken, Bauman'ın (2015: 13-14) ifadesiyle, “akışkan" olan, içinde bulunduğumuz çağda, bir nesne, bir eylem ya da bir mekân üzerinden nostaljinin anlamlarını sorgulamak, günümüz sosyal dünyasının işleyişini sorgulamanın da bir yolunu oluşturur.

\section{Gündelik Hayatta Nostalji ve İșlevleri}

Geçmiş bir zamanda değer ifade eden, özlenen an ve anılar çoğunlukla bir nesne ya da bir mekân ile özdeştir. Gündelik hayatın hemen her alanında geçmişteki bir durum ya da kişiyi çağrıştıran nesne ve mekânların anlam haritasında değer, hafıza, kimlik, geçmiş ve gelecek algısı saklıdır. Nostaljik tutumlar, geçmişe ve geleceğe dair algı yanında içinde yaşanılan sosyal dünyanın bilgilerini de bu algılar üzerinden ele verir. Geçmişin simgeleşerek geleceğe taşınmasında rolü olan, büyüsü bozulmuş dünyalarımıza anlam katan, bireysel ve toplumsal olarak bizi biz yapan hatıraların bağlandığı tüm figürler, yaşadığımız zaman ve mekâna dair algılarımızı ele veren birer sembolik anahtarlardır. Dönemlerin koşul ve özelliklerine göre olumlu ya da olumsuz anlamlar atfedilen nostalji kavramının günümüz toplumunda izini sürmenin, içinde bulunduğumuz dönem ve toplum adına kaydadeğer bir veri sağlayacağını söylemek mümkündür.

Tarihsel olarak bakıldığında nostaljinin özellikle durum ya da yer değiştirilen dönemlerde kendini yeniden tanımlama çabası olarak ortaya çıktığı görülmektedir. Diğer bir ifadeyle nostaljinin yoğun olarak görüldüğü hemen her dönemin ortak özelliği, keskin değişimlerin yaşandığı, Boym'un (2009: 47) ifadesiyle, devrim dönemleri sonrasıdır; devrim sözcüğü, hem döngüsel tekrar hem de radikal kopuş anlamına gelir. Süreklilik ve gelenekteki her derin kopma, yeni bir başlangıç aşamasında "geçmiş" oluşmasına yardımcı olur; yeni başlangıçlar, Rönesanslar, restorasyonlar hep geçmişe dönüş, ondan destek alma biçiminde ortaya çıkarlar ve geleceği ürettikleri, yeniden kurdukları, kapsadıkları ölçüde geçmişi keşfederler (Assmann, 2001: 36).

Nostaljinin işlevi ise tam da bu noktadadır; nostaljik tutum ve söylemler değişimin yaşandığı dönemlerde süreklilik sağlama gibi bir işleve sahiptir. Yine Bauman'ın "City of Fears, City of Hopes" makalesinde devrimler üzerine 
söyledikleri de modern dönemde nostaljinin sıklıkla ortaya çıkışını ve sunumunu anlaşılır kılmaktadır. Zira Bauman'a göre, devrimler modern dönemde eskiye göre daha s1k aralıklarla yaşanmaktadır, hatta devrimler günümüzde bir yaşam tarzıdır (2003: 2). Nostaljinin yaşanan yoğun değişim ve dönüşümler ölçüsünde ortaya çıktığı kabul edildiğinde, günümüzün nostalji furyası Bauman'ın ifadeleri ile kısmen açıklık kazanmaktadır.

Bir hatırlayış biçimi olarak nostalji, temelde hafizanın özlemle hatırlayışı anlamına gelir. Küçük bir simge ya da çağrışım kişiyi geçmişe götürebilir ve hatırlama biçimini koşullandırabilir. Günümüzde hatırlatma işlevine sahip, geçmişe ait pek çok eşya önem kazanmış bağlantılı olarak koleksiyon kültürü yaygınlaşmıştır. Yaygınlaşan bu kültüre yönelik Öztürk, her şeyi biriktirme fikrinin, bir tür genel arşiv oluşturma düşüncesinin, bütün zamanları, bütün dönemleri, bütün biçimleri ve zevkleri bir yere kapama arzusunun ve hatta zamanın dışında yer alacak ve zamanın tehdit edemeyeceği bir mekân oluşturma fikrinin modern döneme özgü olduğunu ifade etmektedir (2012: 65). Boym'a (2009: 17) göre de çağımızın bir belirtisi, tarihsel bir duygu olan nostalji, modernliğin akranıdır. Sanayileşmenin ve modernleşmenin hızlı temposunun, insanların geçmişin yavaş ritimlerine, sürekliliğine, toplumsal kaynaşmışlığa ve geleneğe duydukları özlemi daha da yoğunlaştırdığını vurgulayan Boym'a göre, siberuzaya ve sanal küresel köye duyduğumuz hayranlığa karşılık, en az onun kadar küresel bir nostalji salgını, kolektif hafızası olan bir cemaate duyulan dokunaklı bir hasret, parçalanmış bir dünyada sürekliliğe duyulan bir özlem vardır (2009: 15). Bu bağlamda bireysel ve toplumsal alanlarda geçmişe ait eşyaların biriktirilmesi, sergilenmesi, yeniden üretilmesi ve hatırlatıcı simgelerin yaygınlaşması, modernlik süreci ile birlikte yaşanan değişimlere karşı bir süreklilik direnci ya da kopuşlara bir tepki olarak okunabilir.

Gündelik yaşam içinde nostaljinin izi sürüldüğünde, görülen bir diğer işlevi ise geçmişin bugüne güç verdiğidir. Özyürek'e göre nostalji, toplumun kıyısında köşesinde kalmışlar ya da güçsüzler için bir kaynak işlevi görebilir; bu kişiler kendilerinden bağımsız olarak yüceltilen geçmişin alternatif temsillerini yaratarak, kendileri için şimdide daha iyi bir konum iddiasında bulunabilirler (2008: 202). Dolayısıyla, Özyürek'in ifadesiyle nostalji, şimdiyle ilişki kurup onu dönüştürmenin güçlü ve çok yönlü yollarından biridir (2008: 228). Bu bağlamda, "nostalji, hem bir kaçış hem de bu dünyaya bir alternatiftir ki, bu dünyayı değiştirmek için toplumsal ve siyasal eylem yaratan sadece alternatifler düşüncesidir" (Stauth ve Turner, 1997: 52).

Günümüz nostaljisini, insanların bizzat kendilerinin dönüştürdüğü bir şeyin ardından yas tuttuğu özel bir nostalji biçimi olarak düşünen Tanyeli'ne (2013: 79) göre ise; geçmiş her çağda özlenir; sorun, hangi verilerle tanımlanmış, hangi geçmişin, nasıl özlendiği sorunudur. Yoğun bir özlemin belirtisi olarak ele alınan ve hoşnutsuzluk olarak yorumlanan nostaljinin günümüzdeki kimi görünümlerine bakıldığında, nostaljinin yeni bir yaşam inşa etmede meşrulaştırıcı bir işlevselliğinin olduğu görülebilir. Yeni bir duruma geçiş sürecinde ya da geçildiğinde geçmişe ait imge ve söylemler güven verebilir ve yaşanan değişimleri makul gösterebilir. Connerton'un başka bir şekilde ifade ettiği gibi, günümüzle ilgili deneyimlerimizin büyük ölçüde geçmiş hakkında bildiklerimizin üzerine oturduğu ve geçmişle ilgili imgelerimizin genellikle var olan toplumsal düzeni meşrulaştırmaya yaradığı söylenebilir (2014: 12). Nostalji söz konusu işlevselliklerinden dolayı sadece doğal bir görüntü olarak ortaya çıkmaz aynı zamanda yeniden üretilir ve farklı alanlarda yeniden sunulur: "21. yüzyılın başında nostalji, bir zamanlar dünyanın dört bir tarafındaki kapitalistlerin kamusal ve dolayısıyla pazarlanamaz gördüğü imgeleri ve kavramları özelleştirmekte ve bu suretle metalaştırmaktadır" (Stauth ve Turner, 1997: 19). Söz konusu imge ve kavramların metalaştırılması ya da diğer bir ifade ile nostaljinin bu imge ve kavramlar yoluyla yeniden üretimi yenilenen kentlerde nostajinin görünümüne de 1 ş1k tutmaktadir.

\section{Yeniden Üretim Kavramı ve Nostaljinin Yeniden Üretimi}

Yeniden üretim kavramı, 19. yüzyıldan beri yaygın bir kopya ve kopyalama anlamına sahiptir (Williams, 1999: 185). Üretim biçimindeki değişimle birlikte yeniden üretim hız kazanmış ve var olan ürünlerin yeniden üretimi yaygınlaşmıştır. Connerton'un ifadesiyle, 19 . ve 20. yüzyılların meta kültüründe diğer tüm kelimelerden önce gelebilecek bir kelime varsa, o da "yeni” kelimesidir (2014: 68). Bağlantılı olarak yeniden üretim kavramı, Benjamin, Adorno ve Baudrillard'ın günümüz dünyasına yönelik eleştirilerinde de önemli bir yer edinmiştir.

Walter Benjamin, yeniden üretim kavramını Pasajlar adlı eserinin bir bölümünü oluşturan "Tekniğin Olanaklarıyla Yeniden Üretilebildiği Çağda Sanat Yapıtı" adlı makalesinde sanat bağlamında ele almıştır. Kültür endüstrisi kapsamında bir başyapıt olan bu makalede Benjamin'in belirttiği üzere, aslında insanların yapmış oldukları her zaman insanlar tarafından yeniden yapıla gelmiş aynı şekilde sanat yapıtı da yeniden üretile gelmiştir; yeni olan sanat yapıtının teknik aracılığıyla yeniden-üretilmesidir (1993: 4647). Teknik yoluyla üretim çok sayıda ürünün daha kısa sürede ve kopyalanarak üretilmesinin yolunu açmıştır. On dokuzuncu yüzyıl öncesi her şeyin tek tek el yapımı yapıldığı bir dünya yavaş bir dünyaydı (Connerton, 2014: 40). Tekniğin olanaklarıyla yeniden üretimin yapıldığı günümüz dünyası ise hemen her alanda olabildiğince hızlanmıştır.

Yeniden üretim kavramını kültür endüstrisi kapsamında ele alan Theodor W. Adorno ve Max Horkheimer da eğlence endüstrisinin bir sanat gibi yükselmesini, kültürel ve sanatsal ürünlerin metalaşarak kitlelere sunumunu üretilmiş olanın güncelle yinelenerek tüketilmesi olarak yorumlamış, kültür endüstrisinin temel özelliğini "bildik şeyleri yeni bir nitelikte birleştirmek" (2014: 109) olarak ifade etmişlerdir. Adorno'ya göre kültür endüstrisinin getirdiği asıl yenilik, kültürün uzlaşmaz iki öğesini, sanat ile eğlenceyi amaç kavramına, yani tek bir yanlış formüle, kültür endüstrisinin bütünselliğine tabi kılmış olmasıdır ki bu formül yinelemeye dayanır (2014: 67). Diğer bir ifadeyle kültürel ve sanatsal ürünlerin yeniden üretilmesinin kültürün endüstileşmesinin yolunu açtığını vurgulamışlardır.

Yakın dönemde ise Jean Baudrillard "nesne altkültüründe kültürlüleşme" (1997: 139) olarak tanımladığı kitsch kültürü ile yeniden üretim süreci üzerinde durmaktadır. Kitsch kavramı sanatın ticarileşmesi anlamına gelir. Kitsch (üretimi endüstriyel olabilen) nadir, kıymetli, benzersiz nesneye yeniden değer kazandırır; kitsch ve "otantik nesne" ikisi 
birlikte böylece bugün sürekli hareket ve genişleme halinde olan ayırt edici eşyanın mantığına göre tüketimin dünyasını düzenler (Baudrillard, 1997: 138). Kültürel bir kategori olarak kitschi değerlendiren Baudrillard'a göre her yandan ödünç alınmış göstergelerin nesne düzeyinde endüstriyel çoğalması, bayağılaştırılmasından ve "kullanıma hazır" göstergelerin düzensiz bir artışından kaynaklanan kitschin bu çoğalımı "kitle kültürü" olarak temellerini, tüketim toplumunun sosyolojik gerçekliğinde bulur (1997: 129). Bu hususu daha açık bir şekilde ifade eden Calinescu'ya göre kalabalığı hoşnut eden genellikle kitlesel tüketim için tasarlanmış kitsch, geniş bir kamuoyunun en yüzeysel estetik ihtiyaçlarına ya da kaprislerine anlık tatmin sunmak içindir; bu nedenle yeniden üretilen aynı imge tartışılmaz bir şekilde kitsch olacaktır (2010: 282). Yeniden üretilenin kitsch olması başka bir duruma daha gönderme yapar ki bu Benjamin'in de yeniden üretimde eleştirdiği ve eksik bulduğu taraftır; yapıtın şimdi ve buradalığı. Benjamin'e göre,

Özgün yapıtın şimdi ve buradalığı o yapıtın hakikiliğini oluşturur; dolayısıyla hakikilik, teknik yollarla gerçekleştirilen yeniden üretimin dışında kalır. Bir nesnenin hakikiliği, maddi varlığından tarihsel tanıklığına değin, başlangıçtan bu yana o nesnede gelenekleşmiş olanların bütününden oluşmakta ve sanat yapıtının teknik yoldan yeniden-üretilebildiği çağda ise gücünü yitiren, yapıtın özel atmosferi olmaktadır. Sanatsal üretimde hakikilik ölçütünün iflasıyla birlikte, sanatın toplumsal işlevi de bütün olarak köklü bir değişim geçirmiş; sanatın kutsal törenden temellenmesinin yerini bir başka uygulama, yani sanatın politika temeline oturtulması almıştır (1993: 47-52).

Benjamin'in bir diğer eleştirisi ise yeniden-üretim tekniğinin, yeniden-üretilmiş olanı geleneğin alanından koparıp aldığı yönündedir. Gelenek, (kültür mirasımız) tasarlanmış bir sürekliliğin kendisini açıkça gösterdiği bir süreçtir; bir zorunluluk olarak değil ama arzu edilen bir süreklilik olarak görülen, geçmişin anlamlı bulunmuş ve yeniden yaşanması istenen öğelerinin tekrar tekrar seçilmesi ve yeniden seçilmesi (Williams, 1999: 187) ile oluşur.

Benjamin'in, Adorno'nun ve Baudrillard'ın kültür endüstrisi bağlamında yeniden üretime yönelik yaptıkları eleştiriler, temsiller yoluyla yeniden üretilen geçmişi, hatırlama ve unutma biçimlerindeki sorunlu yönleri açığa çıkarması bakımından oldukça önemlidir. Örneğin kopya edilen ürün, asıl ürünün emek sürecini yok sayar. İmal edilmiş kopya ürünlerin kökene ilişkin düşünce vermemesi gibi, geçmişi temsil eden ürünler yoluyla yapılan hatırlama da yüzeysel ve kısmidir. Daha açı bir ifadeyle, hatırlama tarihsel bağlamından uzaksa hatırlamaya değil daha ziyade unutturmaya hizmet eder. Kültür endüstisinin bir parçası olarak yeniden üretilenin ise tarihsel bağlamından kopuk olduğu rahatlıkla söylenebilir. $\mathrm{Bu}$ anlamda bellek ve kapitalizmin ortak yönlerinin de yeniden üretim olduğunu söylemek mümkündür. Zira, Connerton'un ifadesiyle, kâr ve tüketim odaklı yeniliklerin hızla devasa boyutlarda demode ürünler üretmesinde hayati bir rolü olan unutkanlık, pazarın iyi işleyebilmesi için olmazsa olmaz bir bileşendir (2014: 73).

Nostalji ve yeniden üretimi konusuna gelindiğinde, nostaljinin bir hatırlama biçimi olması ve nostaljik nesnelerin teknik yoluyla yeniden üretimi, yeniden üretim kavramının bellek açısından da kilit önemde olduğunu göstermekte ve hatta kitsch tartışmaları günümüz nostaljisinin hatırlatmaktan çok unutturmaya nasıl hizmet ettiğini açıklamaktadır. $\mathrm{Bu}$ bağlamda, kültürel ürünlerin yeniden üretimi ile belleğin hatırlama işlevi arasındaki ilişkiyi Matei'nin ifadeleriyle özetlemek mümkündür: "Sanat için kiç neyse, hafiza için de nostaji odur" (Matei'den akt. Boym, 2009: 15).

Gözden çıkarılan nesneleri koruma, onlara tarihsel bir hale kazandırma tutkusu, bütün bunlar aslında modernleşme hızına bir tepki, gündelik şimdinin her şeyi bir girdap gibi içine çeken boş uzamından dışarı çıkma ve bir zaman ve bellek duygusu talep etme çabası olarak yorumlanabilir (Huyssen, 1999: 43). Fakat diğer yönüyle geçmişe ait nesnelerin yeniden üretilmesi ya da yeni nesnelere tarihsel bir hale kazandırma tutkusu tüketici odaklı bir ekonominin mantığına oldukça uygundur. Ticarileşmiş nostaljide medeniyetin tüm eserleri seri üretim yoluyla mevcut ve elden çıkartılabilir hale getirilir; böylece tüketici hem modern rahatlığın hem de ilkel fetiş sahipliğinin keyfini sürer (Boym, 2009: 73-74). Yeniden üretilerek ekonominin bir nesnesi olan nostalji, diğer bir ifadeyle, geçmişin imgeler ve temsiller bütününe indirgenmesi, geçmişle bağın kuvvetlenmesine değil zayıflamasına neden olur. Nostaljinin yeniliği meşrulaştırıcı işlevselliği ise buradan kaynaklanır. Bu noktada Herzferd'e kulak verecek olursak;

Burada karşımıza çıkan imajların öne çıktığı bir temsil anlayışıdır. Nitekim postmodern temsil geleneğe başvururken, bir anlam metaforu oluşturmaktan çok geleneği bir imaj olarak tüketir. Bu tarz yerlerde söz konusu olan, "toplumsal olarak deneyimlenmiş bir geçmişin değil, tüm gücüyle varlığını yıkıp yerine geçmeye çalışan sterilize bir geçmişin yeniden resmedilişidir; o geçmiş hiç var olmamış bir şeye dönüştürüldüğü oranda, tarihi umursamayan bir modernliğin teknolojisinden ve ekonomik gücünden beslenen bir nostalji endüstrisi bugünü de istila etmektedir (2011: 401).

Yukarıda ele alınan yeniden üretim üzerinde yapılan tartışmaların bir kısmından hareketle denilebilir ki yeniden üretimde asıl amaç var olanı yaşatmaktan ziyade ekonomiye bir girdi sağlamaktır. Diğer bir ifadeyle burada geçmiş ürünlerinin endüstriyel bir malzeme haline gelmesi söz konusudur.

Yenilenen kentlerde nostaljinin izi sürüldüğünde de nostaljinin kurgusal mekânlar yoluyla yeniden üretildiği ve geçmişin bir pazarlama aracına dönüştüğü rahatlıkla söylenebilir. Örneğin her geçen gün artan nostalji kafeler, gerek sunum gerek tasarımlarıyla müşterilerini adeta geçmişe götürmekte fakat kasada karşılaşılan fiyatlar ya da tutumlar geçmişin samimi günlerinde değil nakit ilişkilerin var olduğu modern zamanlarda yaşandığını vurgulayarak aslında bu yerlerin kurgusal mekânlar olduğunu açık bir biçimde göstermektedir. Yine bu tarz mekân girişlerinde bulunan "-since" eki ile açılış tarihini bildiren tabelalar da dikkat çeken bir diğer durum olarak karşımıza çıkmaktadir. Köklü ve güvenilir esnafın varlığının geçmişe dayandığını bilen mekân işletmecileri yeni açılmış olsalar dahi ayrıntılarda geçmişin gücünü diğer bir ifadeyle nostaljinin işlevselliğini kullanmayı ihmal etmemektedirler. 


\section{Kentlerde Nostaljinin Yeniden Üretimi}

Sanat eserlerinin seri üretim yoluyla hızla üretildiği günümüz dünyasında kentlerde yapılar dahi hılıca inşa edilmekte ve kentlerin büyüyen yapısından hareketle söz konusu yapılar sürekli bir değişim ve dönüşüm geçirmektedir. Gerek kent çeperlerinde gerek kent merkezlerinde yaşanan dönüşümler, yaşam kültürüne ait pek çok öğeyi nostaljiye dönüştürmekle bağlantılı olarak geçmiş yaşama olan özlem ve ilgiyi beslemektedir. Geçmişe duyulan ilgi ve özlem ise öncelikli olarak mekânlara yansımaktadır. Yavaşlık, samimiyet, güvene dayalı ilişkilerle anılan geçmiş; hız, mesafe, nakit ilişkiler ve teknoloji üzerine kurulu olan bugünde mekânlar yoluyla yaşatılmaktadır. Özellikle tarihi kent merkezlerinde görülen nostaljik mekânlar ise bunun bir örneğini oluşturmaktadır. Kent mekânları açısından düşünüldüğünde dış yapısı restorasyona uğrayan; iç yapısı ise güncel ihtiyaçlara göre yeniden düzenlenerek farklı işlevler yüklenen bu tarihi mekânlar, aynı zamanda bir yeniden üretim alanı olarak değerlendirilebilirler. Yine aynı şekilde yakın zamanda inşa edilen binaların nostaljik bir tema ile tarihselliğe büründürülmesi de bu bağlamda değerlendirilebilir. Boyer'e göre, postmodern bir kent alanı kolektif hafizayı canlandıran materyaller ile karakterize edilir; böylece "tarihsel" alanlar yeniden üretilir ya da eski mimari formların bir amalgamı ile yeni binalar inşa edilir (Boyer'den (1996) akt. Mills, 2004: 7). $\mathrm{Bu}$ anlamda kentte tarihsel atmosferi geliştiren restorasyonlar, her ne kadar geçmişin bir kalıntısı olarak görülse de bugün yeniden üretime tabi olan mekânlardır. Boym'un ifadesiyle, hızla dönüşen şehirlerde bu kendiliğinden anma alanları günümüzün kent yenileme fırtınaları karşısında yok olmanın eşiğine gelen tarihsel olanakların sanal düzlemlerini içeren mini müzelerdir (2009: 139). Müze işlevi gören bu tarihsel mekânların kentte konumlanış1, nostaljinin ütopyacı yönünü de içinde barındırır. Huyssen'e göre, nostalji bir anımsama biçimi olarak her zaman ütopyanın içinde vardır ve hatta orada üretici bir işlev üstlenir (1999: 119). Bu mekânlar sadece fiziksel bir yeniden üretime değil aynı zamanda toplumsal bir yeniden üretime de tabi tutulurlar. Kent ve yeniden üretim arasındaki ilişki üzerinde duran Mumford'a göre de; fiziksel ve kültürel gücü yoğunlaştırmasıyla kent, insanlar arasındaki ilişkinin temposunu yükseltmiş, ürünleri stoklanıp yeniden üretilebilir biçimlere sokmuş, sadece fiziksel araçları değil, mirası aktarmak ve geliştirmek için ihtiyaç duyulan insanları da biraraya getirip örgütlemiştir (2007: 684). Bu bağlamda yeniden üretimi, kentin karakteristik özelliklerinden biri olarak görmek, bunu ekonomik açıdan Simmel'in "metropolün her zaman para ekonomisinin merkezi olması" (2003: 85) düşüncesinden hareketle, sosyal açıdan ise mekânlar ve toplumlar arası etkileşim bağlamında okumak mümkündür. Zira günümüzde kentsel mekânın düzenlenmesinde, kültür ve miras endüstrilerini kent ekonomileri için kaynak olarak kullanmayı benimseyen küresel bir kent anlayışı söz konusudur. "Kentin geleceğini kültür endüstrisinde gören özel sektörün ve kamu sektörünün isteklerinin 1980 sonrası neoliberal ekonomiler ve emlak piyasasının talepleri ile belirlendikleri” (Baykan vd., 2011: 126) gerçeği göz önüne alındığında kültür endüstrisinin dünyadaki birçok kentte özelllikle de İstanbul'daki dönüşümü açıklamada hala geçerliliğini koruduğu söylenebilir. Soysal'a göre,

Kentin tarihselleştirilerek yenilenmesi 1980'li yılların başında, bazı bakımsız konakların pastel pembe ve sarıya boyanarak kış bahçeli kafeteryalara dönüştürülmesiyle başlamış, kentin Osmanlı-Rum-Yahudi geçmişinin ortaya çıkarılıp nostalji olarak İstanbulluların tüketimine sunulmasıyla devam etmiş, Miniatürk'ün inşasıyla doruğa ulaşmıştır. Miniatürk'le birlikte, kültürel miras ve tarih artık İstanbullunun yakınına, evinin ötesine taşınmıştır (2011: 393).

$\mathrm{Bu}$ süreç hem kentin kültür endüstrisinin bir parçası olarak ele alındığının hem de kentlerin yerel unsurları ile küresele katılma çabasında olduğunun, dahası yerel unsurların para politikası temelinde değerlendirildiğinin bir ifadesidir. Zira küreseli inşa etmeyre giden yol yereli restore etmekten geçmektedir. Urry'nin de ifade ettiği gibi, bir yere yönelik "nostalji” ve "gelenek" çoğunlukla "cemaat" kavramına dayalı belirli bir estetik eğilimler kümesini dile getiren koruma gruplarınca uydurulmuş olabilmektedir; bu durum, Albert Dock gibi başka türlü olsa metruk bir mülk olarak kalacak yapıların korunması ve gerekli yeni yapıların uluslararası modernist mimari biçemine karşıt olarak yerel biçemde yapılmasının yüreklendirilmesi çabalarına yol açmaktadır (1998: 215). Kısacası kentler bir taraftan küresel etkilerle yeniden yapılanmaya diğer taraftan yine küreselleşmenin etkisiyle tarihsel ve kültürel öneme sahip yerlerin restorasyonlarına sahne olmaktadır. Söz konusu restorasyonlar, kentteki küresel etkilere yerel bir tepki olmaktan ziyade küresel hareketlerin bir parçası olarak gerçekleşmektedir. Bauman'a göre, oyun her iki alanda küresel ve yerel sahnelerde yazılıp oynanmaktadır; sahnelenen oyunların akıbeti birbirlerine sıkıca dolaşmıştır; senarist ve aktörler bu bağın ne kadar derin bir şekilde farkına varırlarsa biri diğerinin üretiminin başarısına o kadar katkıda bulunacaktır (2003: 39).

\section{Yenilenen Kentlerde Nostaljik Görünümler}

Daha önce de belirtidiği üzere nostalji ile bugün hemen her alanda karşılaşılmaktadır; geçmişin muhteşem günlerini vaat ederek geçmişi gelecekte yapacakları çalışmalara referans olarak kullanan siyasi söylemlerden, sundukları şerbetler ve tasarımlar ile Osmanlı dönemini yaşatma iddiasında olan kafe mekânlarına kadar. Fakat kentlerde gerek eski (varlığı geçmişe dayanan) gerek yeni yerleşim yerlerinde bulunan (kurgusal) nostaljik mekânlar, muhakkak ki nostaljinin en görünür olduğu alanların başında gelmektedir. Her iki nostaljik mekânın da, tıpkı nostaljinin gündelik hayatta olduğu gibi, kentlerde kentlerin yapısıyla ilişkili biçimde pekçok işlevi bulunmaktadır. En önemlilerinden biri ise kentlerde yeni gelişmeleri vurgulama işlevidir. Örneğin kentlerde herhangi bir alanda yapılan yeniliğin vurgusu genellikle geçmişteki haline kıyasla yapılmaktadır. Bununla birlikte geçmişten ne zaman dem vurulsa arkasından şimdiyi işaret eden değişimlerin anlatılması olağan bir durumdur. Bu haliyle nostaljiyi, özlemden ziyade yaşanan değişimin ve bu değişimden duyulan memnuniyetin bir ifadesi olarak yorumlamak mümkündür. Dolayısıyla nostaljinin kentlerde konumlanışında, kentlerin doğasına vurgu yapan, zamansal açıdan dün üzerinden şimdiyi ve geleceği vurgulayan bir yönün olduğunu söylemek mümkündür. 
Kentlerde nostaljiyi ortaya çıkaran durumlardan bir diğeri hıza dayalı üretim ve ulaşım sistemlerinin varlığıdır. Kentin hızlı ve yoğun yapısına karşılık nostalji, geçmişin yavaş ritimlerini hatırlatması bakımından dengeleyici bir unsur olarak karşımıza çıkmaktadır. Diğer bir ifadeyle nostalji kentin hızı ve hızlı yaşamı karşısında kentlilere yavaşlık, soluklanma ve zamansal açıdan durup düşünme imkanı sunmaktadir.

Kent yaşamının çoğul ortamında nostaljinin bir diğer işlevi ise kimlik ve kendilik tanımlamalarında oynadığı roldür. Nostalji, küreselleşme karşısında benzeşen birey ve toplulukların kimliklerini vurgulayıcı bir işlev üstlenir. Bireysel ya da kolektif olarak kimlik ve kendilik meselelerinin sembolik bir ifadesi olan nostaljik tutumlar, kent ölçeğinde de bireysel ve kolektif hafıza arasında bir aracı olur. Örneğin özellikle bireysel hafızaların yansıma alanı olan iç mekânlar aynı zamanda toplumsal hafizaları da içlerinde barındırır. Boym'un ifadesiyle koleksiyonlar mahrem deneyimlere sahne hazırlar fakat her dairedeki koleksiyon hem daire sakininin parçalı bir biyografisi hem de kolektif hafiza sergisidir (2009: 475). Nostaljik hatırlama biçimleri bu anlamda bireysel ve toplumsal kimliklerin oluşturulmasında temel bir rol oynar. Kent açısından düşünüldügünde de durum benzerdir. Kentlerdeki nostaljik yapılar, kentlerin bir nevi kimliklerini de vurgular. Bu açıdan şehir Boym'un ifadesiyle, özlem ile yadırgatma, hafiza ile özgürlük, nostalji ile modernlik arasında ideal bir kavşaktır (2009: 249).

Mekân, tarih boyunca iktidarların üzerinde kontrol ve disiplin kurmak için mücadele ettiği alanlardan birisi olmuştur (Öztürk, 2012: 19). Dolayısıyla kentler doğrudan iktidarların etkisinde olan yerlerdir. Kentlerde geçmişin nasıl hatırlanacağı iktidar ilișkilerinden bağımsız olmamıștır. Diğer bir ifadeyle kentlerde geçmişin ele alınışı, nostaljinin kullanımı iktidarların politikaları ile yakından ilişkilidir. Bu açıdan bakıldığında, hatırlamanın ve unutmanın bireysel olduğu kadar ekonomik, sosyal ve politik süreçlerle bağlantılı olarak toplumsal olduğunu da söylemek mümkündür.

Son zamanlarda restore edilerek kullanılan tarihi ve kültürel mekânlar, kentlerde konumlanan nostaljinin siyasi ve ekonomik alanda artan işlevini anlamak açısından da iyi birer örnektir. "Şehrin sembolik coğrafyasındaki bazı değişiklikler, ülkenin siyasi manzarasındaki değişikliklerin tekinsiz habercisidir" der Boym (2009: 249). Bu bakımdan geçmişteki önemli kişi, yer ve olayları sembolik olarak yaşatan pekçok nostaljik yapının izini sürmek günümüzde hem yapısal olarak hem de siyasal olarak yaşanan değişimlerin yönünü görebilmek açısından önemlidir.

Özyürek'e göre, hatıra geçmişten ziyade çağdaş iktidar ilişkilerini ve yapılarını yeniden şekillendiren bugüne dair bir eylemdir (2008: 201). Bu noktada başlı başına bir inceleme konusu olmayı hak eden siyaset ve nostalji ilişkisi, siyasette nostaljinin kullanımı ile iktidar olmanın, iktidarda kalmanın ve sonrasında da hatırlanmanın bir aracı olması yönüyle önem arz eder. Bu ilişkinin yansıdığı alanların başında kentler gelmektedir. İktidar mücadeleleri kentlere sembollerin mücadelesi olarak yansır. Her iktidar kendi değerlerini anıtlaştırıp kendi nostaljisini bugüne taşımaya çalışırken, Boym'un tabiriyle; yeniden inşa sembolik bir misilleme biçimi olmaktadır (2009: 270). Geçmişi kendi parametrelerine göre yorumlayan günün iktidarı, geleceğin de iktidarı olma isteğini bu yeniden inşa biçiminde ele vermektedir. $\mathrm{Bu}$ bağlamda iktidar ve hatırlama arasındaki ittifakın ileriye dönük yanını vurgulayan Assmann'a göre:

Hükümdarlar sadece geçmişi değil aynı zamanda geleceği de gasp eder, hatırlanmak isterler, bu yüzden kendilerini unutturmayacak işler yapar ve bu eylemlerinin anlatılması, müziksel olarak işlenmesi, anıtlarda sonsuzlaşması ya da en azından arşivlenmesi için çaba gösterirler. Kısaca iktidarlar, kendisine geriye yönelik meşruluk, ileriye yönelik ebedilik kazandırırlar (2001: 73).

Söz konusu işlerin ve eylemlerin yeri ise çoğunlukla yapılanın görülebildiği kentlerdir. Özyürek'e göre, tarih yazımında kendilerine yer bulamayan kişisel deneyimler ya da üzerinde konuşulması zor konular, edebiyat, anı, müzik, sinema gibi kültürel ürünlerde dile getirilebiliyorlar; bu ürünlerin üretimi, dolaşımı ve tüketimi kadar anlatılan deneyimlerin hakikiliğine yönelik iddialar da toplumsal belleği şekillendirmede alternatif bir mücadele alanı oluşturuyor (2001: 11). Geçmişin farklı yorumlara açık oluşu, geçmişe ait kültürel miras niteliğinde olan tarihi yapıların da iktidarların sunduğu miktarda farklı kesimlerce farklı yorumlanmasının önünü açar. Bu gibi durumlarda iktidarların geçmişi nasıl ve hangi yönleriyle ele aldığı, söz konusu yapıların yıkım, yenilenme ve kullanımları üzerinde de anahtar rol üstlenir.

Kentlerdeki nostaljik semboller aynı zamanda gündelik hayatta siyasetin izini sürme olanağı da sağlar. Yerel siyasi kültürü şekillendiren ve dönüştüren yönüyle nostalji ve özelleştirme arasındaki karşılıklı bağların gelişiminin izini süren Özyürek'e göre, nesneleri, ilişkileri ve kavramları metalara dönüştüren neoliberal ideolojinin arkasındaki önemli devindirici iki kuvvetten biri nostalji, diğeri ise özelleş(tir)medir (2001: 17). Bu bağlamda Özyürek' in 75. yıl kutlamalarını incelediğinde vardığı sonuç, piyasaya dayalı sembollerin, niyetlerinden bağımsız olarak, yeni siyasal ifade ve katılım biçimlerini getirdiği ve devlet sembollerini devletin dişında görülen alanlara taşıyarak yeni anlamlar kazandırdığıdır. Özyürek, kamusal-özel, siyasal-siyasal olmayan, meşru-gayri meşru alanlar arasında hızla aşınan sınırları işaret ederek, "hem toplumun hem de devletin yerine pazarı koymayı amaçlayan neoliberal sembollerin popülerleşerek, güçlü devlet ideolojileri ve devlet güdümlü modernleşme projelerinin nostaljik anılarıyla yeni bağlamlara tercüme edilmekte" olduğunu ifade eder. Yine O'na göre bu durum siyasetin siyasi kurumlardan ziyade bu kurumlar dışında aranabileceğini, siyasetin gündelik hayatta semboller üzerinden izinin sürülebilmesinin daha makul olduğunu göstermektedir. Çünkü siyasetin yeni biçimi oy verme ve seçimin ötesinde daha önceleri özel ya da mahrem diye düşünülen alanlarda ve eylemlerde gerçekleşmektedir (Özyürek, 2001: 39). Dolayısiiyla siyaaysetten ziyade kent mekânlarında izi sürülen nostalji daha açık bir toplum okuması için oldukça sağlam veri sağlayacaktır. Örneğin söz konusu durum Türkiye örneğinde düşünüldüğünde bir kesim Cumhuriyet dönemine nostalji duyuyorken başka bir kesim Osmanlı dönemine nostalji duymakta; siyaset, gerek siyasi arenada gerek gündelik hayatta bu nostalji temellendirmeleri üzerinden sürdürülmektedir. Özyürek'in deyimiyle, her iki kesim de (Kemalistler ve İslamcılar) şimdiyi dönüştürecek bir turnusol kağıdı olarak geçmişin nostaljik temsilinden yararlandığından, geçmiş siyasal meşruiyet ve tahakküm 
mücadelesinin arenası haline dönüşmektedir (2001: 202). Bu anlamda kurumsal iktidarı meşrulaştırma biçim ve söylemleri için nostalji etkin bir araç olmakta ve siyasi alanda nostalji, kendini tanımlama, meşrulaştırma ve gelecekte konumlandırmaya hizmet etmektedir. Sonuç olarak, Özyürek'in ifadesiyle, "piyasa temelli ekonomi ve siyaset, tam da kendi doğasından ötürü, insanların ev içi mekânı nasıl düzenledikleri, hayat hikâyelerini nasıl anlattıkları ve siyasal gelişmeler hakkında neler hissettikleri noktasında şekilleniyor ve elbette sonrasında da dönüp bunları yeniden şekillendiriyor" (2001: 40).

Günümüzde kentler gerek para politikalarının gerek siyasi politikaların merkezinde olan yerlerdir. Nostalji ise her iki alanda da oldukça işlevsel bir potansiyele sahiptir. Bu açıdan bakıldığında kent yenileme çalışmaları sürecinde kentlerdeki her iki aktörün söylemlerinin, eylemlerinin ve bunların yansıması olan kentlerdeki görüntülerin daha derinlikli bir analizine imkan vermektedir. Nostalji üzerine yapılan tüm bu tartışmalar geniş bir perspektifle ele alındığında kent merkezlerinde yürütülen restorasyon ve yenileme çalışmalarının ya da geçmişin güzel günlerinin yeni bina satışlarında pazarlanmasının da ötesinde yeni yerleşim yerlerinde kurgusal bir çerçevede tasarlanan nostaljik mekânların varlığı da anlaşılır olmaktadır.

\section{Sonuç}

Çalışmada vurgulandığı üzere kent mekânlarında nostaljinin konumlanışında, kentlerin doğasına (hızlı değişim ve dönüşüm) vurgu yapan, zamansal açıdan şimdiyi vurgulayan, küreselleşme karşısında yereli ön plana çıkaran bir yan bulunmaktadır. Dahası bu mekânlar geçmiş ve gelecek, geleneksel ve modern, küresel ve yerel arasındaki karşılıklı etkileşimlerin merkezinde yer almaktadır. Dolayısıyla kentin dönüşümünde etkin olan iki temel aktörün söylemlerinde ve uygulamalarında görülen nostalji, birbirine bağlı ekonomik, politik ve kültürel süreçlerin etkileşimi bağlamında ele alındığında anlaşılabilir olmaktadır. $\mathrm{Bu}$ bağlamda gerek para politikalarından gerek siyasi politikalardan hareketle hızlı bir dönüşüme tabi tutulan sadece kentler değil aynı zamanda kentlilerin belleğidir de. Kentlerin ve kentlilerin belleği niteliğinde olan nostaljik yer ve yapıların ifade ettiği önem sadece geçmişi hatırlama, unutmama açısından değil kentlerin geleceği açısından da kuşkusuz büyük önem taşımaktadır. Fakat literatürdeki tartışmaların da odak noktası olan nostaljinin endüstrileşmesinin hatırlatmaktan ziyade unutturduğu gerçeğinden hareketle, kentlerde tarihi bina ve yerlerin para politikalarına tabi bir dönüşüme tutulmasının geçmişi hatırlatmaktan ve yaşatmaktan çok belirli bir alana sıkıştırarak yeni yapılanmanın önünü açması sonucunu verdiğini söylemek mümkündür.

Diğer bir açıdan bakıldığında hızla yenilenen ve büyüyen kentlerin fiziksel ve kültürel değerlerini kaybetme tehlikesiyle karşı karşıya olduğu kent çalışmalarında sıkça dile getirilmektedir. $\mathrm{Bu}$ bağlamda son yıllarda yerel yönetimlerce kentin değerli tarihi yapılarının restorasyonlarına önem verildiği, tarihi kent merkezleri için ise dönüşüm projelerinin gündeme geldiği görülse de kentlerin genel yapısına ve yaşadıkları dönüşüme bakıldığında kültürel miras eserlerinin restorasyonları ve tarihi kent merkezlerinin yenilenmesi ile kentin fiziksel ve kültürel değerlerini korumak bir yana, bu tarihi bina ve merkezlerin onarımlarının kentin geri kalanının dönüşümü için hem bir lokomotif hem de meşrülaştırici bir işleve sahip olduğu görülmektedir. Zira yeni yapılanma şeklinin kentin var olan özgün yapısıyla uyuşmaması ve yapılan dönüşümlerin bütünsellikten uzak olması bunun en bariz göstergeleri olmaktadır. Bu anlamda kentlerde nostaljinin ortaya çıkışını ve yaygınlaşmasını ekonomik açıdan üretim biçimindeki değişimin, kültürel açıdan ise yaşam biçimindeki değişimin bir yansıması olarak değerlendirmek mümkündür. Nostalji ve kent ilişkisi üzerinde durmak, politik açıdan ise kentlerin siyasetle olan bağına 1şık tutma potansiyeline sahiptir.

\section{Kaynakça}

Adorno, T. W. (2014), Kültür Endüstrisi - Kültür Yönetimi, Çev. Elçin Gen, Nihat Ülner, Mustafa Tüzel, İstanbul: İletişim Yayınları.

Assmann, Jan (2001), Kültürel Bellek: Eski Yüksek Kültürde Yazı, Hatırlama ve Politik Kimlik, Çev. Ayşe Tekin, İstanbul: Ayrıntı Yayınları.

Bauman, Z. (2003), City of Fears, City of Hopes, London: Goldsmiths College, 18.07.2018 tarihinde http://www.arss.ro/wpcontent/uploads/2009/07/z.bauman_city-of-fear.pdf adresinden alındi.

Bauman, Z. (2015), Akışkan Modern Dünyada Kültür, Çev. İhsan Çapcioğlu ve Fatih Ömek, Ankara: Atıf Yayınları.

Baudrillard, J. (1997), Tüketim Toplumu, Çev. Hazal Deliceçaylı ve Ferda Keskin, İstanbul: Ayrıntı Yayınları.

Baykan, A. vd., (2011), Yaşayan Bir Tarihi Miras Alanına İlişkin Muhalif Durumlar: Büyük Valide Han, Istanbul Nereye? Küresel Kent, Kültür, Avrupa, haz. Deniz Göktürk vd. İstanbul: Metis Yayınları.

Benjamin, W. (1993), Pasajlar, Çev. Ahmet Cemal, İstanbul: Yapı Kredi Yayınları.

Beatriz, S. (2011), Geçmiş Zaman: Bellek Kültürü ve Özneye Dönüş Üzerine Bir Tartışma, Çev. Peral Bayaz Charum ve Deniz Ekinci, İstanbul: Metis Yayınları.

Boym, S. (2009) Nostaljinin Geleceği, Çev. Ferit Burak Aydar, Istanbul: Metis Yayınları.

Calınescu, M. (2010), Modernliğin Beş Yüzü, Çev. Sabri Gürses, İstanbul: Küre Yayınlar1.

Connerton, P. (2014), Toplumlar Nasıl Anımsar? Çev. Alâeddin Şenel, İstanbul: Ayrıntı Yayınları.

Connerton, P. (2014), Modernite Nasıl Unutturur, Çev. Kübra Kelebekoğlu, İstanbul: Sel Yayıncılık.

Demir, S.T. (2017), The Stranger to Time: What a Collector Stands for in a Hurried Society, Human Studies, Springer Netherlands, March Volume 40, Issue 1, pp. 43-59. 
Herzferd, M. (2011), İstanbul: Kaleydoskopta Kültür Politikas1, Istanbul Nereye? Küresel Kent, Kültür, Avrupa, Haz. Deniz Göktürk, vd., İstanbul: Metis Yayınları.

Huyssen, A. (1999), Alacakaranlık Anılarl: Bellek Yitimi Kültüründe Zamanı Belirlemek, Çev. Kemal Atakay, İstanbul: Metis Yayınlar1.

Mills, A. (2004), Streets of Memory: The Kuzguncuk Mahalle in Cultural Practice and Imagination, $\mathrm{PhD}$ Thesis, The University of Texas at Austin.

Mumford, L. (2007), Tarih Boyunca Kent, Çev. Gürol Koca ve Tamer Tosun, İstanbul: Ayrıntı Yayınları.

Özyürek, E. (2008), .Modernlik Nostaljisi, Çev. Ferit Burak Aydar, İstanbul: Boğaziçi Üniversitesi Yayınevi.

Özyürek, E. (2001), Hatırladıklarlyla ve Unuttuklarlyla Türkiye'nin Toplumsal Hafizası, Ed. Esra Özyürek, İstanbul, İletişim Yayınları.
Simmel, G. (2003), Modern Kültürde Çatışma, Çev. Tanıl Bora, Utku Özmakas, Nazile Kalaycı, Elçin Gen, İstanbul: İletişim Yayınları.

Soysal, L., vd.: (2011) Istanbul Nereye? Küresel Kent, Kültür, Avrupa, Haz. Deniz Göktürk vd., İstanbul: Metis Yayınları.

Stauth, G., TURNER, B. S. (1997), Nietzsche'nin Danst: Toplumsal Hayatta Hınç, Karşıllklılık ve Direniş, Çev. Mehmet Küçük, Ankara: Bilim ve Sanat Yayınları.

Tanyelı, U. (2013),

Rüya, İnşa, İtiraz: Mimari Eleştiri Metinleri, İstanbul: Boyut Yayınları.

Urry, J. (1998), Mekânları Tüketmek, Çev. Rahmi Öğdül, İstanbul: Ayrıntı Yayınları.

Williams, R. (1999), Kültür, Çev. Suavi Aydın, Ankara: İmge Yayınları. 